\title{
Persistence of Spatial Layout Concept as the Basis for Conservation of the Baluwarti Settlement of Surakarta
}

\author{
Tri Hartanto \\ Department of Architecture, Tunas Pembangunan University, Surakarta, Indonesia \\ trihartanto74.utp@gmail.com
}

\begin{abstract}
This research was conducted in the Baluwarti settlement of Surakarta. This settlement was once the royal city of the Surakarta Hadiningrat palace, which was founded in 1745. The Surakarta Hadingrat Palace was built in 1742 by Paku Buwana II. In 1748 Paku Buwana II died, and was replaced by Paku Buwana III. During his reign, Paku Buwana III began to build a settlement area for soldiers, sentana dalem, and abdi dalem which is currently known as the Baluwarti settlement. One of the objectives of this research is to explore the concept of settlement spatial layout. By using historical studies research methods, it is known that the concept of settlement spatial layout is "manunggaling kawula lan gusti". Then the exploration of the concept of spatial layout continued until today (Paku Buwana XIII era). Based on the elements of spatial layout that are still and are still being maintained, it can be concluded that the spatial concept from the time of Paku Buwana III to Paku Buwana XIII is still being maintained. The Baluwarti settlement is a cultural heritage area of Solo City, and at the same time is a legacy of historical value, according to the Decree of the Mayor of Surakarta Number 646/116/i/1997 concerning the Determination of Ancient Historic Buildings and Areas in the Municipality of Surakarta. In this effort to conserve settlement areas, it also faces the same problems as in other places, including the absence of a clear concept in preservation so that the local community has not carried out conservation of the area properly. So that from the results of previous research, namely the concept of spatial layout which was maintained from the beginning until now (manunggaling kawula lan Gusti), will become the basic concept in preserving the settlement area of Baluwarti Surakarta.
\end{abstract}

Keywords: Baluwarti, Concept, 'Manunggaling Kawula lan Gusti', Preservation, Settlement

Introduction

Apart from the architecture with a distinctive spatial pattern, the people in the Baluwarti settlement still adhere to the customs, habits, procedures and culture that originate from the Surakarta Palace. This peculiarity is what makes the residential environment in the Baluwarti area included in the cultural heritage area of Solo City, and at the same time is a legacy of historical value, according to the Decree of the Middle Mayor of the Surakarta Level II Region Number 646/116 / i / 1997 concerning the Designation of Buildings and Areas Ancient History in the Municipality of Surakarta. In the effort to preserve this residential area, it also has the same problems as in other places. Based on the author's study in 2015 , there are at least five issues / problems faced in the preservation of residential areas, including: a) regulation; application of laws and regulations in the field that have not been realized properly, b) there is no clear concept in area preservation; so that the local community has not carried out conservation of the area properly, c) funding; mostly still dependent on government subsidies, d) conflicts of interest; can come from inside and from outside the conservation area, and e) low community participation. Regarding the problem of the concept of preservation and the low level of community participation, it is hoped that the results of this study will provide solutions, in the form of information and understanding to the community about the concept of residential spatial planning, which is full of noble palace cultural values, so that it can be preserved and maintained for future generation. 


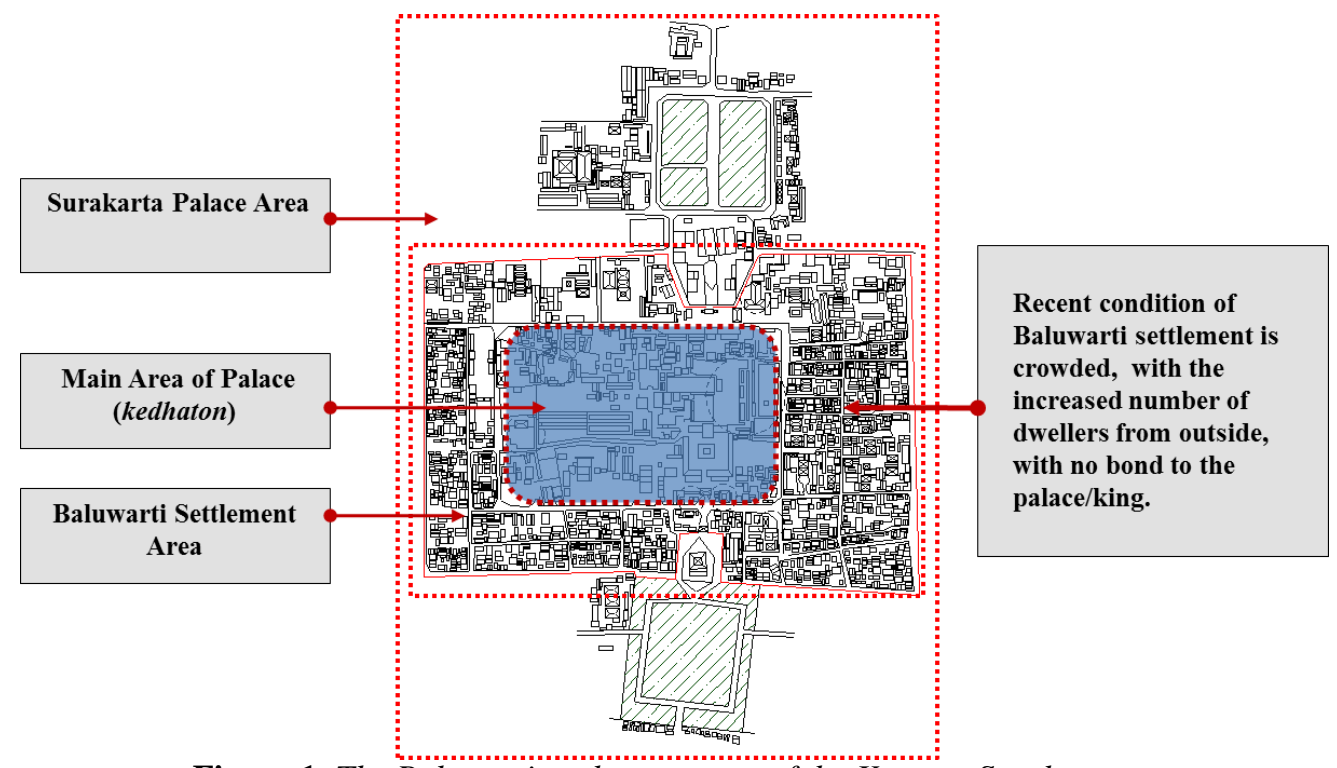

Figure 1. The Baluwarti settlement, part of the Keraton Surakarta

Solikhah.N, Setijanti.P, and Soemardiono. B, (2010) based on the results of his study offers a revitalization concept that is applied to the Baluwarti area, the concept used is the concept of revitalizing a sustainable area (sustainability), in the form of a balance between physical characteristics, utilization of economic potential, and preservation of the social values of the Baluwarti area. Then Pratomo, A.S, Sudikdo. A, and Hariyani. S, (2006) expressed his thought that conservation priorities are recommended for ancient buildings that have high cultural values, especially their historical role values. Meanwhile, Wiwit.W (2010) in the publication of research results entitled 'Priority for the Conservation Strategy of Kauman Surakarta Area with the Revitalization Concept Approach' conveyed several things that must be considered, including: a). physical potential in the form of ancient buildings (houses, langgar, religious buildings) as well as settlement patterns within the area, b). while non-physical potential is in the form of a history of its relationship with the Kasunanan Surakarta Palace, as well as regional specific activities, namely batik and religious activities, c). the absence of regulations protecting the existence of the area, inadequate conservation funding, the absence of an area master plan, community empowerment, assistance, decreasing the vitality of the area's physical environment, as well as developing local specific activities that are still not optimal, d) to increase the effectiveness of priority sequences, are : 1). revitalization of Kauman as a batik village, 2). revitalization of Kauman as a santri village, 3). revitalizing Kauman as a tourist village.

According to Yuliana, K.K and Kurniati, (2013) in efforts to conserve Kauman Semarang Village as a Cultural Tourism Area, the following should be pursued: a). still preserving traditional building forms, $b$ ). holding a night market to liven up the Kauman area at night, c). religious activities that are routinely carried out by the Kauman community, to be maintained, d). reviving youth organizations in villages so that teenagers know and explore culture / traditions, the Department of Regional and City Planning, Faculty of Civil Engineering and Planning ITS, (2012) in the Surabaya Bubutan Area Preservation concept approach provides directions, including: a) forming a working network between the government, academics / professionals, and local communities to add value to the cultural heritage area, b) provide counseling or provide information related to the importance of preserving cultural heritage areas, c) involve the community in meetings, discussions, contribute personnel in maintaining cultural heritage buildings.

Based on the study of the research results that have been published above, that in the concept of conservation / preservation of 
residential areas there are two main elements that must be considered, namely: 1) the physical elements of the area in the form of objects / buildings / environment, and 2) elements. a non-physical area in the form of belief / religion held by the surrounding community, has been going on for a long time and has become a tradition. The two elements are tied to each other, where the non-physical elements affect the physical elements of the residential area.

\section{Methodology}

The research method used is historical studies by reading history (historical reading). Historical studies are used to find out the initial concept of the spatial layout of the Baluwarti settlement that was built, through books or chronicles describing the conditions at that time, documents / archives / magazines / articles, and newspapers, pictures from that period, and surviving artifacts. So that it can be used to see the elements of the Baluwarti settlement spatial structure that still survive today. Furthermore, a qualitative inductive approach with in-depth interviews is used to reveal the factors that influence the community and still uphold the values of tradition and culture as forming the uniqueness of the traditional Baluwarti settlement spatial layout.

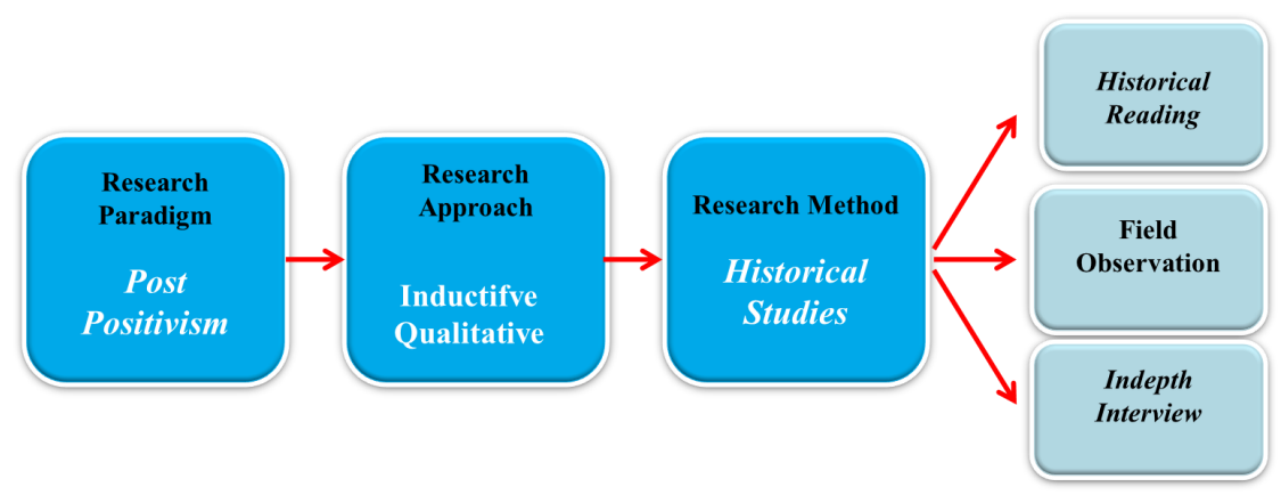

Figure 2. Paradigm, Approach, and Research Methods

\section{Results and Discussion}

The spatial pattern of the Baluwarti settlement has distinctive characteristics and is different from other traditional settlement spatial layouts. The physical spatial layout of the settlement is influenced by non-physical elements of settlement spatial planning which are derived from the palace culture and traditions, as follows: a) the area is surrounded by Baluwarti fortress, so it is protected from enemies, b) access in and out of the area is only in two points, namely in the north (kori brajanala lor) and in the south (kori brajanal kidul), c) cosmological orientation, covering the four corners of the eye of the wind, d) regional orientation, oriented towards kedhaton (king), where the king is considered to have certain privileges, f) circulation patterns / road networks around the kedhaton (king), g) residential patterns in groups and close together due to high kinship, h) the form of residential buildings according to status and title. 


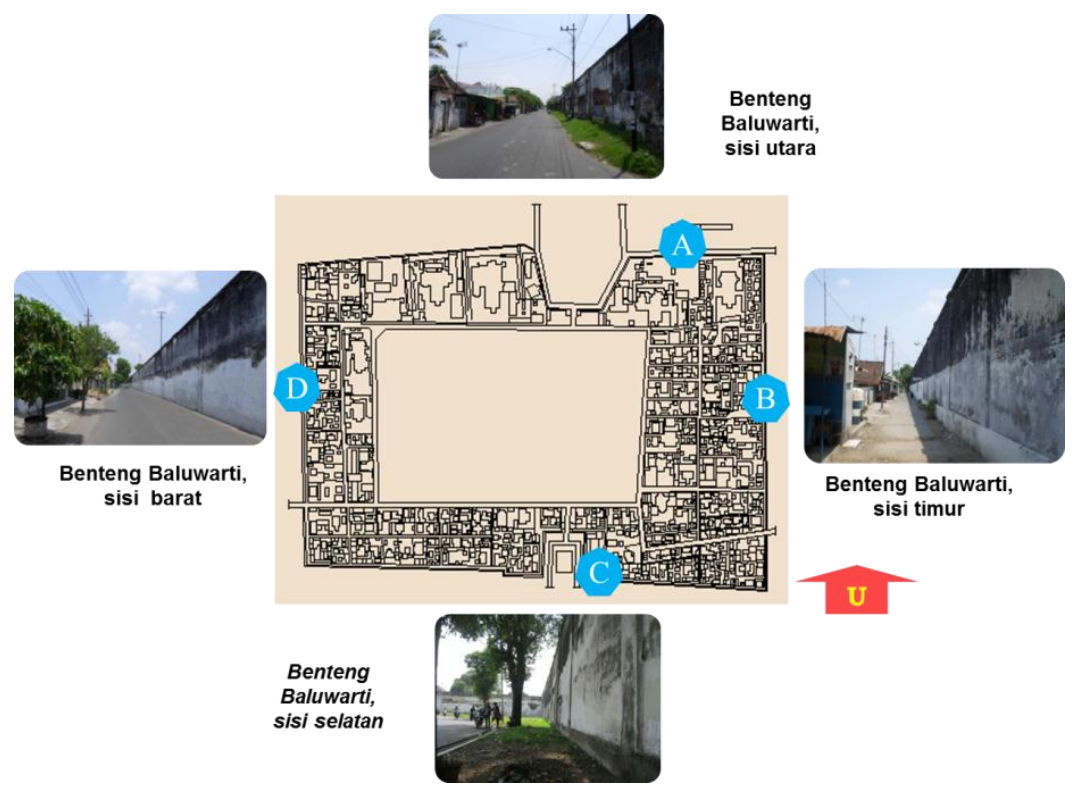

Figure 3. Baluwarti Fortress surrounds the Baluwarti Settlement

The traditional and cultural values of the palace which are also non-physical elements forming the uniqueness of the Baluwarti settlement spatial planning are: (a) the king/palace is trusted and respected by the people/kawula, because as panata gama, protector of Javanese customs and cultural traditions, (b) title and status, indicating the role, status and position of a person, which is obtained based on the service that has been given to the king/palace, (c) the magersari system, the granting of land and buildings to subordinates who devote their lives to the king. The traditional ceremonies created by the Surakarta court poets contain meaning in every detail of the ceremony. The main purpose of the ceremony is to place each member of society in a certain social position, as king, sentana, servant of the dalem, and kawula (Kuntowijojo, 1987: 40-41).

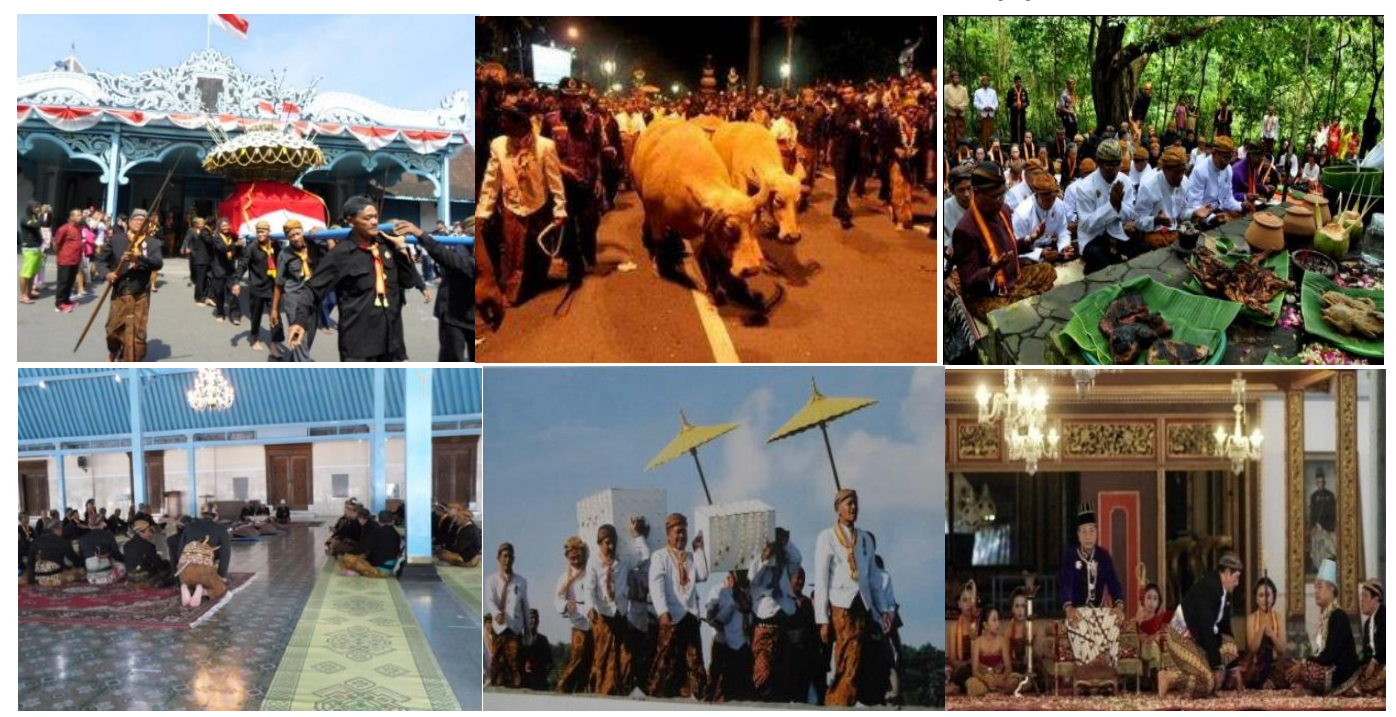

Figure 4. Traditional ceremony (tradition) of the Kasunanan Surakarta Palace: Grebeg, Kirab Pusaka, Mahesa Lawung, Labuhan, Pasowanan Ngabekten 
Based on the results of the analysis, the traditional and cultural values of the palace contained in the elements of residential spatial planning which have noble values and high awareness of the Baluwarti community in adhering to tradition are believed to be the underlying concepts of the sustainability of the embodiment of the Baluwarti settlement spatial plan as a forum for community activities. in an effort to achieve harmony and harmony in the life of the people of Baluwarti Surakarta. The initial concept of the spatial layout of the Baluwarti settlement which was built during the reign of Paku Buwana III was manunggaling kawula-gusti. Where this concept is a manifestation of serving the king, preserving tradition and culture, and creating security, which can be realized if there is unity and togetherness between the king and his people / subordinates.

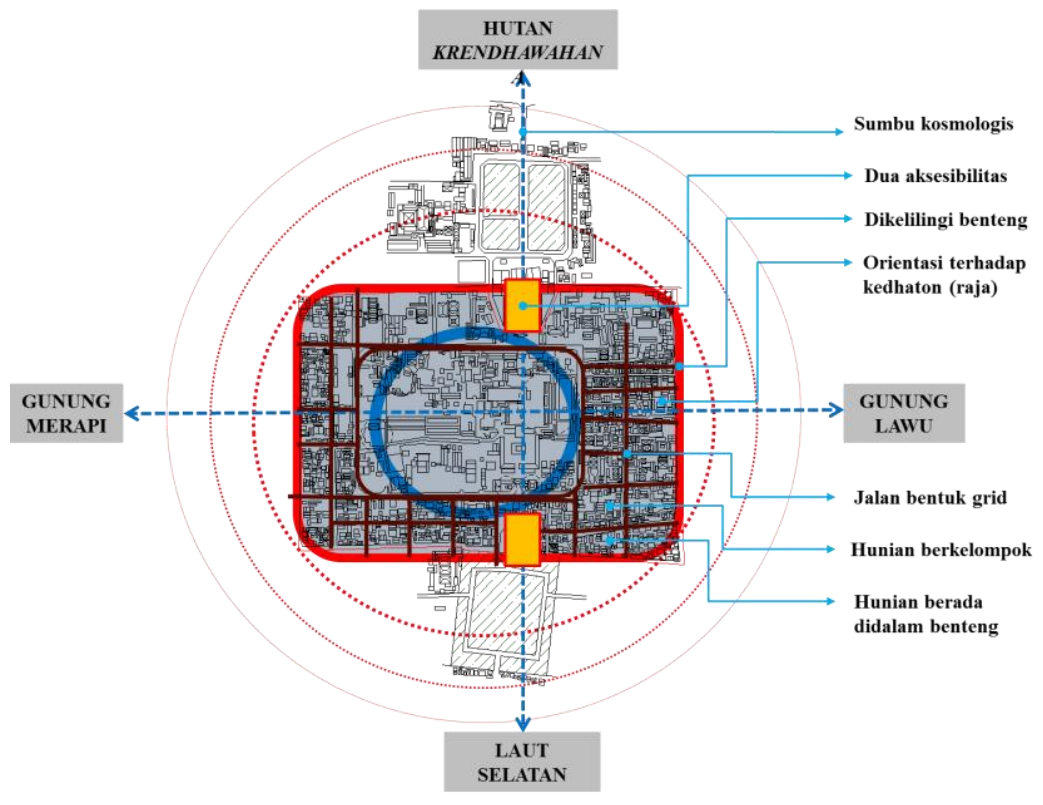

Figure 5. The Concept of Spatial Planning as a Security System

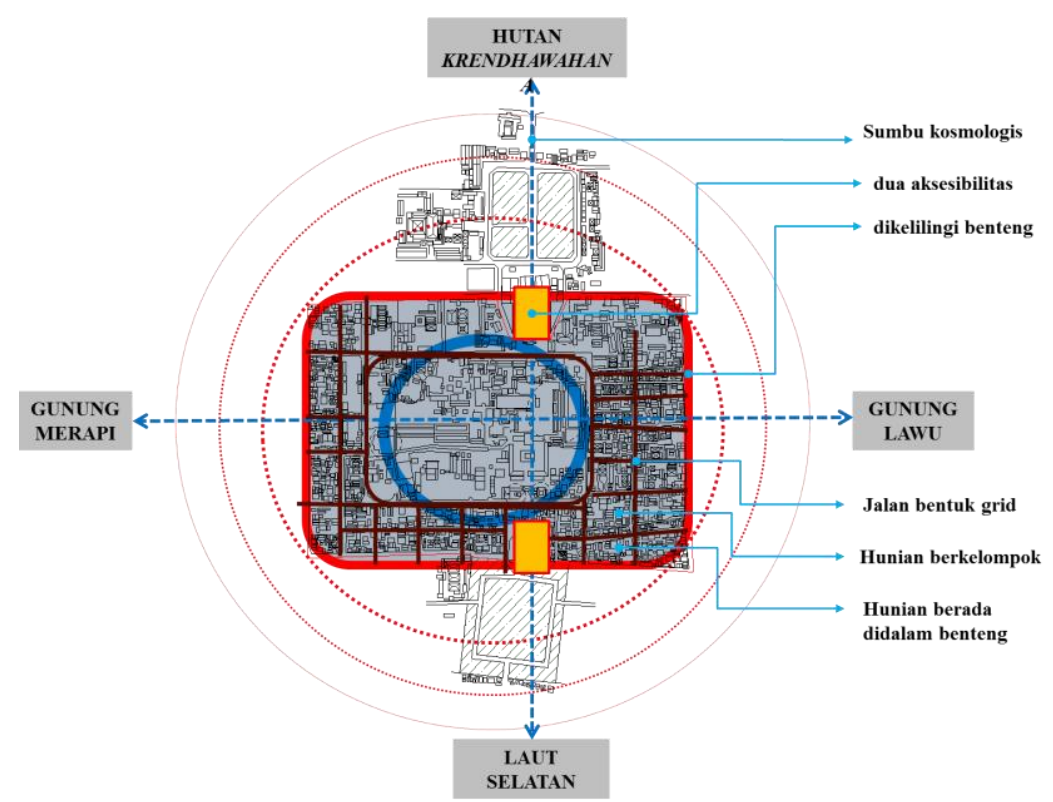

Figure 6. The Concept of Spatial Planning as a Service System to the King 


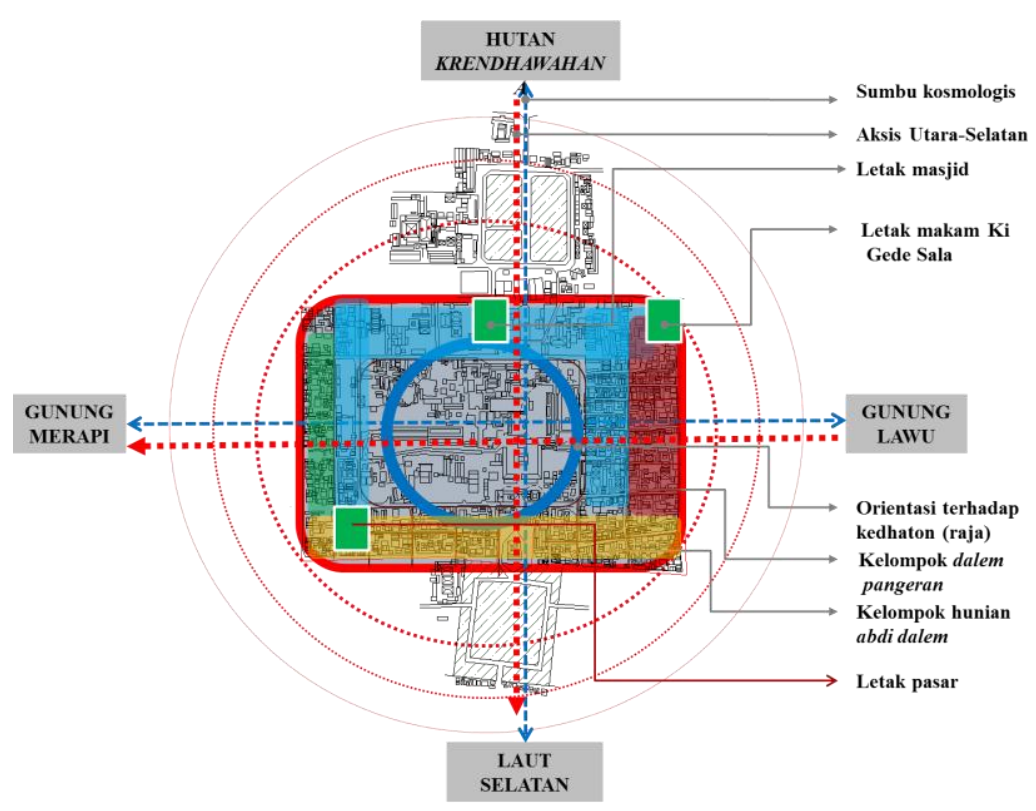

Figure 7. The Concept of Spatial Planning as a System of Preserving Tradition and Culture

Based on tracing and identification of spatial elements diachronic, the spatial layout of the Baluwarti settlement during the Paku Buwana III period is still maintained today. This can be seen based on the existence and sustainability of the elements of the Baluwarti settlement spatial planning, both physical and non-physical elements. Physical elements of spatial planning that are still maintained, namely: (a) zoning; division of the area based on sacred values, front zone, side zone, and back zone. Where the groups / occupancy zones form concentric patterns around the kedhaton (king), (b) orientation; the orientation of the Baluwarti settlement formed a concentric pattern with a single orientation, namely the kedhaton (king), (c) the North-South axis; the area axis starts from the Brajanala Lor to the Brajanala Kidul, (d) the circulation pattern; the main road circulation of the pradaksina, while the secondary road network is oriented towards the kedhaton (king), (e) building layout; based on status and profession, (f) model / pattern; the dwelling is a grid pattern, in groups and around the kedhaton (king). The non-physical elements of the Baluwarti spatial plan that have survived to the present day include: (a) belief and religion systems, (b) magersari system, and (c) status and titles. The concepts that underlie the formation of the spatial sustainability of the Baluwarti settlement are a manifestation of public awareness of the idea of achieving harmony and harmony in life which comes from Javanese cultural values (kraton) which are imbued with Islamic teachings. The values of the basic concept include: hablum minnallah, hablum minannas, and hablum minna alam which is called Tri Hanakara.

The embodiment of the spatial layout of the Baluwarti settlement in Surakarta, implies public awareness of ideas originating from the values and goals to be achieved by the king and the royal family, as well as the people who live in the Baluwarti settlement. In this case, the embodiment of the spatial layout of the Baluwarti settlement with various elements, both physical elements / non-physical elements and its derivative concepts, is based on public awareness of the idea of achieving Tri Hanakara, namely harmony with the environment, harmony in social life and welfare for all communities based on the values of local beliefs / beliefs and wisdom.

Tri Hanakara is the guidance and purpose of human life as a personal and social being, which is manifested in various behaviors, structures, rules, activities, and a forum for human activity. Tri Hanakara is a transcendental value that has become the 
awareness and knowledge of the community of Baluwarti Surakarta settlements, thus influencing various activities / activities and the manifestation of community activities. Every activity and manifestation of a community activity forum is a process and a means to achieve harmony, harmony and prosperity for the entire community. This is reflected in the community's efforts to always maintain a harmonious relationship in life with Allah SWT / God Almighty, human relations, and relationships with the universe.
Allah SWT / God Almighty is recognized as the Almighty who determines the various activities / activities of society to achieve harmony, harmony and prosperity in life both in the world and in the hereafter. Therefore, Tri Hanakara is seen as an important "capital" in maintaining the sustainability of the area, because it becomes a guideline for the community in determining the direction of development (preservation) of residential areas that need to be preserved.

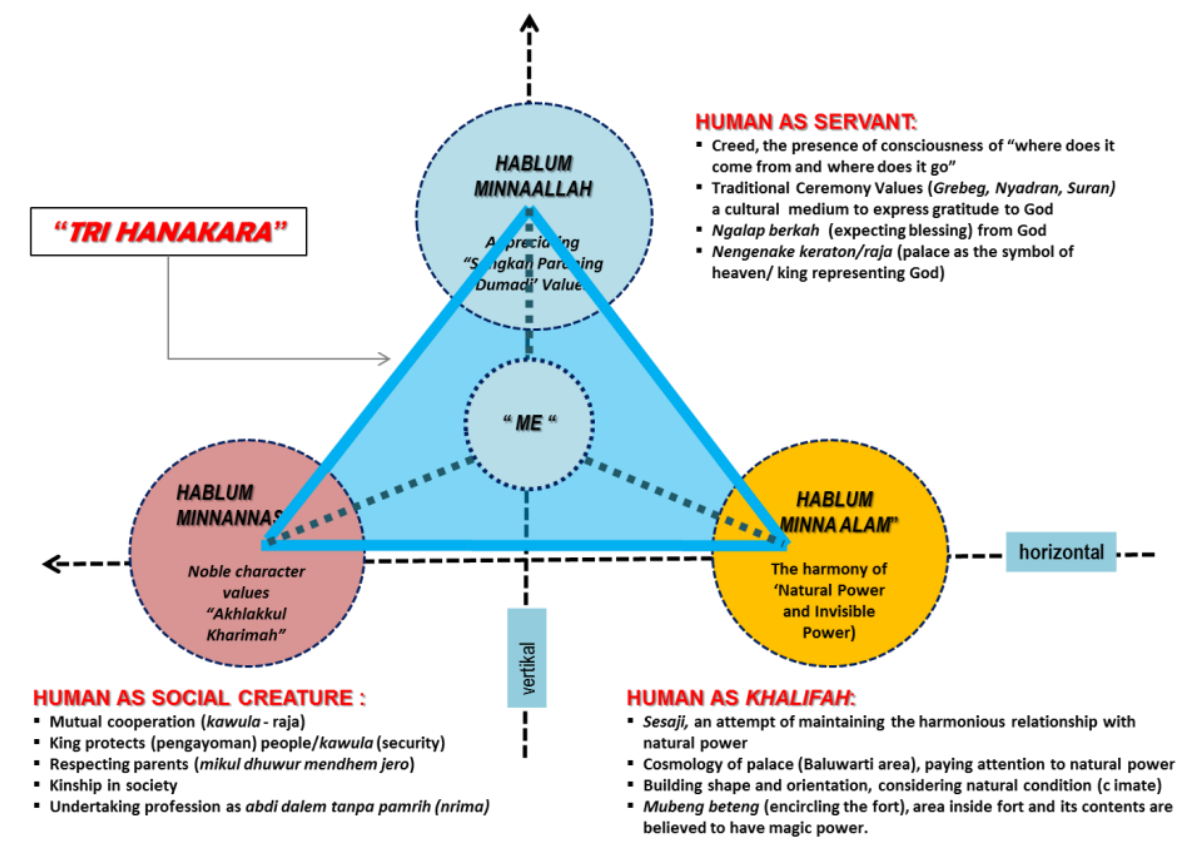

Figure 8. Tri Hanakara Concept as the Baluwarti Community's Consciousness of Maintaining the typical characteristics of Settlement's Spatial Layout

Efforts to formulate policies regarding the arrangement, development, or preservation of traditional settlements in Java are important, because these settlements are not limited only as a forum for activity, but are a manifestation of people's efforts to achieve the Tri Hanakara, namely harmony and harmony for the entire community. In achieving Tri Hanakara, it is necessary to have a balance between hablum minallah, hablum minannas, and hablum minna alam, which is manifested in the arrangement, development, or preservation of settlements. 


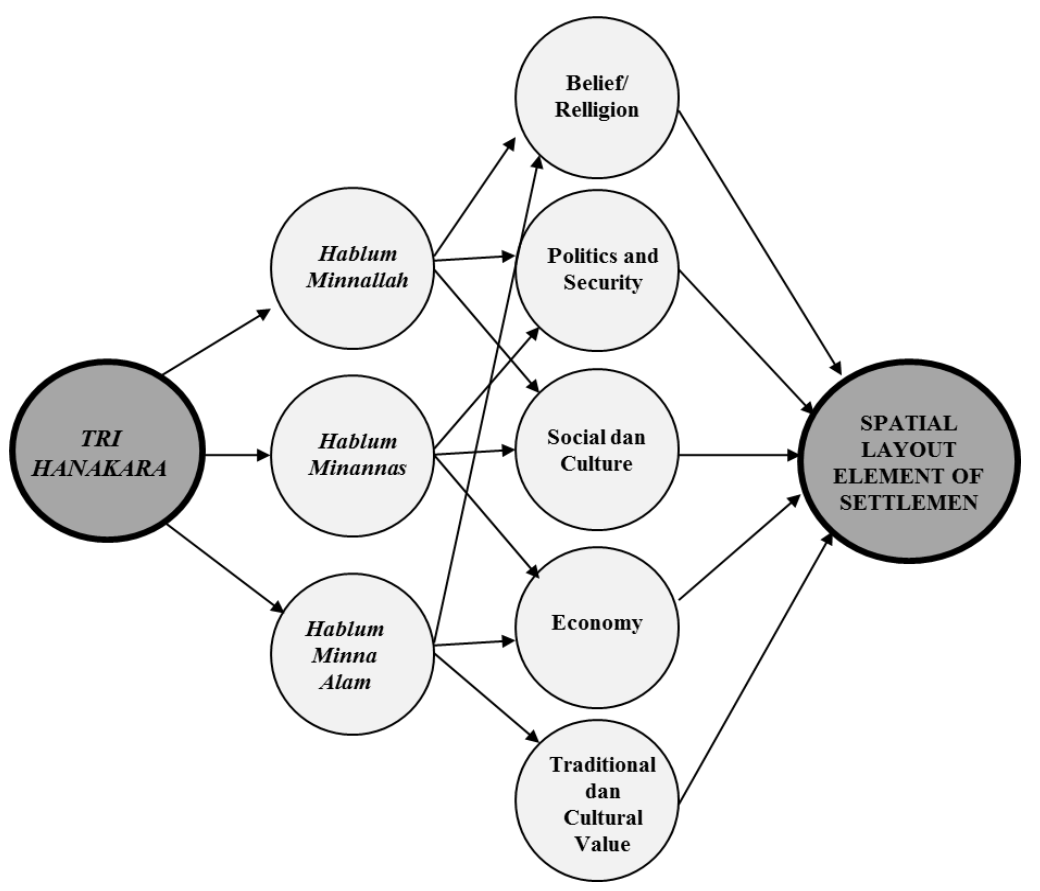

Figure 9. Tri Hanakara Concept as the Basis for Conservation Baluwarti Setlement

In formulating policies, it is necessary to pay attention to several main aspects that influence the achievement of the Tri Hanakara, namely: (1) aspects of belief / religion, as part of the application of the value of the minimum habit; (2) political and security aspects as part of the application of the value of hablum minallah and hablum minannas; (3) social and cultural aspects as part of the application of the value of hablum minannas which is based on the value of hablum minallah; and (4) economic aspects as part of the application of the natural mineral value and part of the application of the natural mineral value; (5) aspects of the traditional and cultural values of the palace as part of the application of the value of natural minna, as part of the application of the value of hablum minannas which is based on the value of hablum minallah. Thus, the arrangement, development or preservation of settlements is not only the responsibility of several parties, but must involve more community participation through development programs that empower the community more.

\section{Conclusion}

The resilience of the Baluwarti settlement spatial planning is inseparable from the existence of the Baluwarti fortress and the consistency of most of the Baluwarti people who still adhere to the traditional values and culture of the palace as a way of life in everyday life. This is driven by the desire to create harmony in the life of the world to the afterlife, while maintaining a good relationship with God, good relationships among humans, and a good relationship with the environment. This harmony can be achieved by carrying out the following efforts: (a) preserving the traditions and culture of the ancestors; a manifestation of the belief / religion of the Baluwarti community, (b) creating (a sense of) security; a manifestation of the magersari system, (c) serving (raving blessings) to the king / palace; manifestation of the status and title of preparing dalem.

In the realm of traditional settlement preservation practices, the Tri Hanakara concept can be a solution to one problem of how to determine the concept in area preservation. Where the value of the concept of preservation must consider and accommodate spatial elements that are able to maintain the relationship between humans and God, the relationship between humans and humans, and humans and nature in a balanced manner. If these three elements 
form the basis of the concept of preserving settlements (areas), then these conservation efforts will produce a harmonious, harmonious and comfortable area.

\section{Acknowledgements}

Thanks to all those who have contributed in the preparation of this research report, all resource persons, the government of Baluwarti village, Kasunanan Surakarta Palace, and Ristekdikti.

\section{References}

Andri Satrio Pratomo dkk. 2006. Pelestarian Kawasan Kampung Batik Laweyan Kota Surakarta. DIMENSI TEKNIK ARSITEKTUR Vol.34, No.2, Desember 2006.

Kartika Y.K, Kurniati. R. 2013. Upaya Pelestarian Kampung Kauman Semarang Sebagai Kawasan Wisata Budaya

...., 2012. Pelestarian Kawasan Bubutan. Prodi Perencanaan Wilayah Dan Kota Fakultas Teknik Sipil Dan Perencanaan
Institut Teknologi Sepuluh Nopember (ITS), Surabaya

Nafi'ah Solikhah dkk. 2010. Studi

Perkembangan Dan Konsep Revitalisasi

Tata Lingkungan Tradisional Baluwarti

Surakarta. Program Magister Jurusan

Arsitektur, FTSP-ITS Surabaya

Nurul Sri Hardivanti dkk. 2005. Studi

Perkembangan Dan Pelestarian

Kawasan Keraton Kasunanan Surakarta.

Dimensi Teknik Arsitektur Vol.33, No.1,

Program Studi Perencanaan Wilayah dan

Kota, Universitas Brawijaya.

Puspita, D.Y . 2008. Urban Heritage Conservation In Surakarta, Indonesia: Scenarios And Strategies For The Future

Suparwoko. 2011. Sistem Informasi Konservasi Bangunan Bersejarah Berbasis Stakeholders Di Kota Yogyakarta. jurnal penelitian : Bappeda kota Yogyakarta.

Republik Indonesia. 2010. Undang-undang No.11 Tentang Cagar Budaya

Wijayanti. W. 2010. Prioritas Strategi Konservasi Kawasan Kauman Surakarta Dengan Pendekatan Konsep Revitalisasi 